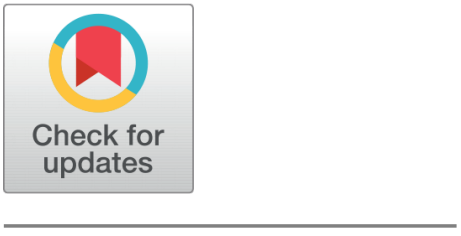

OPEN ACCESS

Received: 29.03.2021

Accepted: 14.07.2021

Published: 30.07 .2021

Citation: Ananthakeshava I, Srikanth NJ, Prasad KN, Vinu V (2021) Reduction in Surface Tension of Water Due to Pranic Healing. Indian Journal of Science and Technology 14(26): 2175-2179. https ://doi.org/10.17485/IJST/v14i26.488

* Corresponding author.

research@pranichealing.co.in

Funding: None

Competing Interests: None

Copyright: @ 2021 Ananthakeshava et al. This is an open access article distributed under the terms of the Creative Commons Attribution License, which permits unrestricted use, distribution, and reproduction in any medium, provided the original author and source are credited.

Published By Indian Society for Education and Environment (iSee)

ISSN

Print: 0974-6846

Electronic: 0974-5645

\section{Reduction in Surface Tension of Water Due to Pranic Healing}

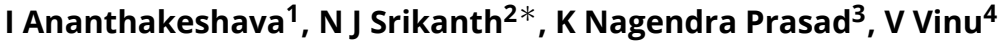 \\ 1 Research consultant, World Pranic Healing Foundation India Research Centre, Mysore, \\ India \\ 2 Research Head, World Pranic Healing Foundation India Research Centre, Mysore, India \\ 3 Senior Research consultant, World Pranic Healing Foundation India Research Centre, \\ Mysore, India \\ 4 Research Associate, World Pranic Healing Foundation India Research Centre, Mysore, India
}

\section{Abstract}

Objective: To study the effects of Pranic Healing (PH) on surface tension of water. Methods: This study involved the application of the PH on water and observing the changes in the surface tension (ST) values. ST was measured in the Pranic and Control using the Capillary rise method and the data were analyzed using Mann- Whitney $U$ test. Findings: The results showed that the ST of water reduced significantly, after 20 minutes in the PH-treated samples, when compared to control. Additionally, contact angle also reduced due to $\mathrm{PH}$, showing an increase in wettability. It has given indications that the Pranic healing could be used in modulating the physical property of water. Novelty: Pranic Healing, reduces the ST of water, which would be beneficial since it directly affects the absorption of nutrients by living beings from the fluid medium.

Keywords: Biofield; Complementary therapy; Energy Healing; Prana; Water

\section{Introduction}

Over $70 \%$ of earth surface is covered by water. The reduction of water surface tension (ST) is beneficial for soil water retention. Certain plants, roots release rhizodeposits which act as surfactants in soil, which help water retention of soil ${ }^{(1,2)}$. It has been stated as early as in 1912 that, if water's ST reduces, it would be more permeable through cell membrane. The lower ST also increases the $\mathrm{CO}_{2}$ vapour concentration in water in plants ${ }^{(3)}$. The fact that lower ST improves the absorption of nutrients by plants has led to the use of surfactants from the middle of the 20th century ${ }^{(4)}$. The water's surface tension may also be reduced by mechanical methods like misting, used in fog-ponics to improve the irrigation efficiency ${ }^{(5)}$. Non-chemical methods like magnetically treating the water ${ }^{(6)}$, application of microwaves to reduce the ST of water ${ }^{(7)}$ have advantages over chemical methods. Still, the transport to location of use, the setting up, cost of installation, and maintenance aspects can pose limitations in people using them.

The change in Water's surface tension value by Energy healing was first observed in the 1970s, from the observations of experiments conducted separately by Worrall, Kathryn Hill, and Miller ${ }^{(8)}$. The phenomenon of 'Altering the Water's property 
by human intentions alone, was verified by Emoto M. and the team ${ }^{(9)}$. Pranic Healing $(\mathrm{PH})$ is a complementary therapy where healer projects Prana or vital energy or the bio-plasmic energy onto the subject, without physical contact ${ }^{(10,11)}$. In Pranic Healing, the vital energy level is sensed and changed to improve the health condition of the subject. Therefore, PH also may be classified as a biofield healing ${ }^{(12)}$. The $\mathrm{PH}$ as an energy-healing modality has been studied on plants, and better results have been observed in terms of the growth rate of seedlings ${ }^{(13)}$, vegetative growth characteristics ${ }^{(14)}$; nutritional content and yield per plant ${ }^{(15)}$. This led to investigate whether Pranic healing influences properties of water.

\section{Materials and Methods}

De-mineralized (DM) water (Spectrum Reagents) was used in this study, since it has minimal contaminations. Traveling microscope (KAYCO, India) with Least Count: $0.01 \mathrm{~mm}$ and Capillary tubes (Inner radius $1.045 \mathrm{~mm}$ ) was used for this study.

\subsection{Method}

This is a controlled study with 2 groups. One group is untreated (control) and the other group is treated (it undergoes Pranic Healing and called Pranic group). To determine the ST, Capillary rise was measured. Two beakers with $25 \mathrm{ml}$ DM water were placed on a common surface. One Capillary tube each is immersed into each beaker from the capillary tube holder. The capillary height of water in both the beakers is observed using a traveling microscope. The levels of water surface in the beakers were noted at the beginning and also at the end of the experiment; Pranic healing is applied to the Pranic group as suggested by Sui ${ }^{(10)}$, while for the control group it was left untreated. Surface tension was calculated by measuring the capillary height of water as described below ${ }^{(16,17)}$.

Knowing ' $r$ '- the radius of the capillary tube and observing ' $h$ ' - the Surface tension 'T' is calculated according to the expression

$$
T=(r \times(h+(r \div 3)) \times \rho \times g) \div(2 \times \cos \theta)
$$

Where:

$\mathrm{g}$ is the acceleration due to gravity, $9.8 \mathrm{~m} / \mathrm{s}^{2}$.

$\rho$ is the density of water, considered the nominal value $1 \mathrm{~kg}$ per litre.

$\theta$ is the angle of contact. The angle $\theta$ being tiny, considered zero, making $\cos \theta=1$.

\subsection{Statistical Analysis}

The data collected have been analysed and tabulated as a mean value \pm standard error (SE) of five replicates for each treatment. The analysis was performed using SPSS version 21, and the data was analysed using Mann-Whitney U test.

\section{Results \& Discussion}

Results show that there was no significant difference in surface tension values of water in pranic and control group before healing $(\mathrm{z}=.000, \mathrm{U}=12.500, \mathrm{p}=1 \mathrm{n} . \mathrm{s}$.). During 10 minutes, the ST values of control and pranic were found to be 72.49 and 67.69 and the results were insignificant $(\mathrm{z}=0.000, \mathrm{U}=3.000, \mathrm{p}=0.056 \mathrm{n} . \mathrm{s}$.) (Table 1). After, 10 minutes, a significant difference in surface tension of water in pranic group were found, when compared to control and the results were significant $(\mathrm{z}=-2.62, \mathrm{U}=0.000, \mathrm{p}=$ 0.008) (Figure 1). Beyond $20 \mathrm{~min}$, the ST of Pranic sample reduced further and the same trend is noticed till 90 min, while for the control the values were consistent from 10 to $90 \mathrm{~min}$ and the results were significant.

Table 1. Mann- Whitney Test Results of Surface Tension of Water

\begin{tabular}{llllllllll}
\hline & Before & $10 \mathrm{~min}$ & $20 \mathrm{~min}$ & $40 \mathrm{~min}$ & $50 \mathrm{~min}$ & $60 \mathrm{~min}$ & $70 \mathrm{~min}$ & $80 \mathrm{~min}$ & $90 \mathrm{~min}$ \\
\hline $\mathrm{U}$ & 12.50 & 3.00 & 0 & 0 & 0 & 0 & 0 & 0 & 0 \\
$\mathrm{Z}$ & 0 & -1.991 & -2.619 & -2.619 & -2.619 & -2.619 & -2.619 & -2.619 & -2.619 \\
$\mathrm{Sig}$ & 1 & 0.056 & 0.008 & 0.008 & 0.008 & 0.008 & 0.008 & 0.008 & 0.008 \\
\hline
\end{tabular}




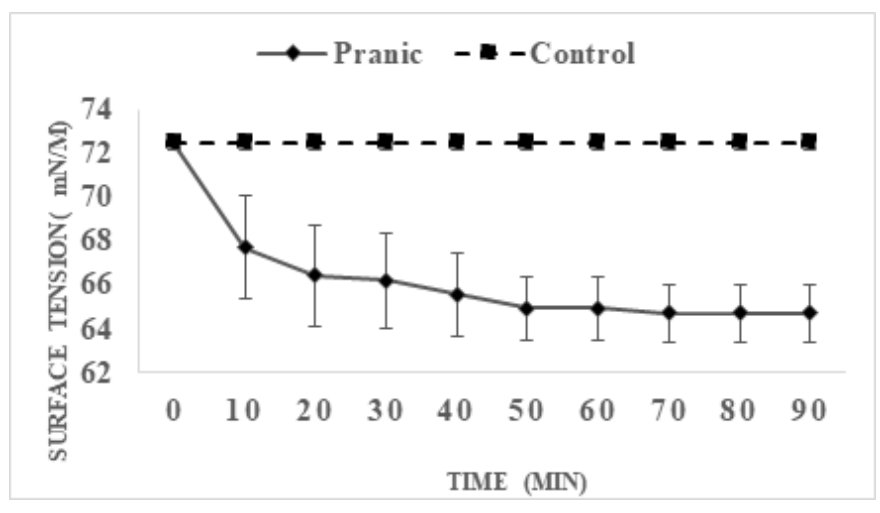

Fig 1. Effect of Pranic Healing on Surface Tension of Water

\section{Contact Angle $(\theta)$}

While continuously observing the top meniscus of water in the capillary tube, it came to notice that the contact angle $(\theta)$ also is changing - towards reducing from the initial value. The images in Figure 2 depict the reduction in contact angle post - Pranic Healing.

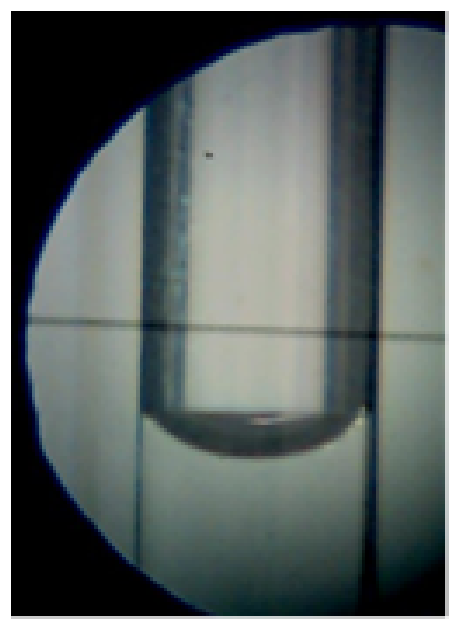

Control

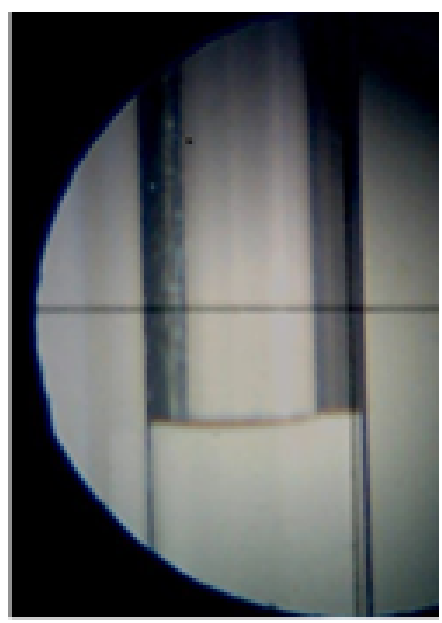

Treated

Fig 2. Contact angle of control and treated water sample.

The hydrogen bonds at the air-water interface greatly contribute to the surface tension. ${ }^{(18)}$. The studies suggest that the hydrogen bonds in water break by adding surfactants and magnetization ${ }^{(19)}$, causing a reduction in surface tension. With that background information, it may be thought that the hydrogen bonds get ruptured due to Pranic Healing causing reduction in ST. Only by further studies it would be possible to analyse the Root cause behind this phenomenon. The literature suggests that reduced surface tension of water is beneficial to the biological activities of living beings; and also in medicinal and surgical fields. The decrease in surface tension makes the liquid less sticky, easy to flow; the blood and bio-fluids in animals and plants. The lower surface tension of water also makes it difficult for insects and their eggs, larvae to float on the surface; restricting their propagation ${ }^{(20)}$. Majority of water content in plant cells is used up in transpiration. To improve the transpiration, the hydrogen bonds in water need to be broken or the surface tension needs to be reduced ${ }^{(21)}$. Reduction of surface tension by surfactants would help to avoid the lung collapse, when anesthesia is administered to the body for surgeries ${ }^{(22)}$.

A reduction in contact angle means lower the Surface Tension of water. The reduction in surface tension increases water's wetting ability to wet the surfaces ${ }^{(23)}$. The reduction in contact angle of water with a surface implies increased wettability. 
Increasing the wettability has agricultural ${ }^{(24)}$, industrial ${ }^{(25)}$ and medical applications for reducing granule size and improve absorbance by the body ${ }^{(26)}$. Lower surface tension of medicines such as nasal drops, ophthalmic medicines help them spread on the target surface, crossing mucous - layer that normally exists over these surfaces ${ }^{(27)}$. Using the surfactants along with fertilizers is in practice to reduce the ST of water ${ }^{(4)}$.

\section{Conclusion}

It has been observed that the surface tension of water can be decreased. Its wettability may also increase due to Pranic Healing. The application of Pranic Healing $(\mathrm{PH})$ to alter the physical properties of liquids can have a wide range of applications in Agriculture, Medicine, and Industry. The improvement in wettability of water by Pranic Healing would have multiple implications when correlated to the aspects like altered capabilities of blood and body fluids in supply efficiency of nutrients to cells. Further work using tap water and how PH reduced the ST of water and the mechanism behind it needs to be investigated.

\section{References}

1) Vesala T, Sevanto S, Grönholm T, Salmon Y, Nikinmaa E, Hari P, et al. Effect of Leaf Water Potential on Internal Humidity and CO2 Dissolution: Reverse Transpiration and Improved Water Use Efficiency under Negative Pressure. Frontiers in Plant Science. 2017;8(54). Available from: https: //dx.doi.org/10.3389/fpls.2017.00054.

2) Naveed M, Ahmed MA, Benard P, Brown LK, George TS, Bengough AG, et al. Surface tension, rheology and hydrophobicity of rhizodeposits and seed mucilage influence soil water retention and hysteresis. Plant and Soil. 2019;437(1-2):65-81. Available from: https://dx.doi.org/10.1007/s11104-019-039399.

3) McClendon JF. The osmotic and surface tension phenomena of living elements and their physiological significance. The Biological Bulletin. 1912;22(3):113162. Available from: https://dx.doi.org/10.2307/1535938.

4) Huang Z, Zhang S, Wang H, Liu R, Cheng C, Liu Z, et al. Umbrella" Structure Trisiloxane Surfactant: Synthesis and Application for Reverse Flotation of Phosphorite Ore in Phosphate Fertilizer Production. Journal of Agricultural and Food Chemistry. 2020;16(40):11114-11120. Available from: $10.1021 /$ acs.jafc.0c04759.

5) Sabrina Z, Kamron Z. The Effect of Surface Tension on Plant Growth in Fogponics. 2018. Available from: https://abstracts.societyforscience.org/Home/ PrintPdf/18484.

6) Amiri MC, Dadkhah AA. On reduction in the surface tension of water due to magnetic treatment. Colloids and Surfaces A: Physicochemical and Engineering Aspects. 2006;278(1-3):252-255. Available from: https://dx.doi.org/10.1016/j.colsurfa.2005.12.046.

7) Parmar H, Asada M, Kanazawa Y, Asakuma Y, Phan CM, Pareek V, et al. Influence of microwaves on the water surface tension. Langmuir. 2014;26(33):9875-9884. Available from: 10.1021/la5019218.

8) White JW, Krippner S, editors. Future science: Life energies and the physics of paranormal phenomena. 1977.

9) Radin D, Hayssen G, Emoto M, Kizu T. Double-Blind Test of the Effects of Distant Intention on Water Crystal Formation. Explore. 2006;2(5):408-411. Available from: https://dx.doi.org/10.1016/j.explore.2006.06.004.

10) Sui CK. Pranic healing" Institute for Inner Studies, Publishing Foundation India Private Limited. Bangalore, India. 1992.

11) Rubik B, Muehsam D, Hammerschlag R, Jain S. Biofield science and healing: history, terminology, and concepts. Global advances in health and medicine. 2015;4:8-14. Available from: 10.7453/gahmj.2015.038.suppl.

12) Jain S, Hammerschlag R, Mills P, Cohen L, Krieger R, Vieten C, et al. Clinical studies of biofield therapies: Summary, methodological challenges, and recommendations. Global advances in health and medicine. 2015;4:58-66. Available from: 10.7453/gahmj.2015.034.suppl.

13) Prasad KN, Jois SN. Enhancement of Papaya (Carica papaya) Seedling Growth by Pranic Agriculture. AGRIVITA Journal of Agricultural Science. 2020;42(1):191-196. Available from: https://dx.doi.org/10.17503/agrivita.v42i1.2410.

14) Prasad KN, Jois S. Effect of Pranic agriculture on vegetative growth characteristics of spinach (Spinacia oleracea L.). Indian Journal of Science and Technology. 2020;13(24):2446-2451. Available from: https://doi.org/10.17485/IJST/v13i24.711.

15) Poornima R, Prasad KN, Jois SN. Growth, yield and nutritional content of finger millet (Eleusine coracana L.) as influenced by pranic energy application. Journal of Applied and Natural Science. 2021;13(1):42-50. Available from: https://dx.doi.org/10.31018/jans.v13i1.2463.

16) Richards TW, Carver EK. A critical study of the capillary rise method of determining surface tension, with data for water, benzene, toluene, chloroform, carbon tetrachloride, ether and dimethyl aniline. Journal of the American Chemical Society. 1921;43(4):827-847. Available from: https://dx.doi.org/10. 1021/ja01437a012.

17) Danov KD, Stanimirova RD, Kralchevsky PA, Marinova KG, Stoyanov SD, Blijdenstein TBJ, et al. Adhesion of bubbles and drops to solid surfaces, and anisotropic surface tensions studied by capillary meniscus dynamometry. Advances in Colloid and Interface Science. 2016;233:223-239. Available from: https://dx.doi.org/10.1016/j.cis.2015.06.003.

18) Hauner IM, Deblais A, Beattie JK, Kellay H, Bonn D. The Dynamic Surface Tension of Water. The Journal of Physical Chemistry Letters. 2017;8(7):15991603. Available from: https://dx.doi.org/10.1021/acs.jpclett.7b00267.

19) Zhou Q, Qin B, Ma D, Jiang N. Novel technology for synergetic dust suppression using surfactant-magnetized water in underground coal mines. Process Safety and Environmental Protection. 2017;109:631-638. Available from: https://dx.doi.org/10.1016/j.psep.2017.05.013.

20) Estellé P, Cabaleiro D, Zyła G, Lugo L, Murshed SMS. Current trends in surface tension and wetting behavior of nanofluids. Renewable and Sustainable Energy Reviews. 2018;94:931-944. Available from: https://dx.doi.org/10.1016/j.rser.2018.07.006.

21) Filipović A. Water Plant and Soil Relation under Stress Situations. InSoil Moisture Importance. IntechOpen. 2020. Available from: 10.5772/intechopen. 93528.

22) Riveros-Perez E, Riveros R. Water in the human body: An anesthesiologist's perspective on the connection between physicochemical properties of water and physiologic relevance. Annals of Medicine and Surgery. 2018;26:1-8. Available from: https://dx.doi.org/10.1016/j.amsu.2017.12.007.

23) Hussien OS, Elraies KA, Almansour A, Husin H, Shuhili JABM. Beyond fracking: Enhancement of shale gas desorption via surface tension reduction and wettability alteration. Journal of Natural Gas Science and Engineering. 2018;57:322-330. Available from: https://dx.doi.org/10.1016/j.jngse.2018.07.011. 
24) Goebel MO, Woche SK, Bachmann J, Lamparter A, Fischer WR. Significance of Wettability-Induced Changes in Microscopic Water Distribution for Soil Organic Matter Decomposition. Soil Science Society of America Journal. 2007;71(5):1593-1599. Available from: https://dx.doi.org/10.2136/sssaj2006.0192.

25) Li JJ, Zhu LT, Luo ZH. Electrospun fibrous membrane with enhanced swithchable oil/water wettability for oily water separation. Chemical Engineering Journal. 2016;287:474-81. Available from: https://doi.org/10.1016/j.cej.2015.11.057.

26) Avrămescu RE, Ghica MV, Dinu-Pîrvu C, Udeanu D, Popa L. Liquid Marbles: From Industrial to Medical Applications. Molecules. 2018;23(5):1120. Available from: https://dx.doi.org/10.3390/molecules 23051120.

27) Han K, Woghiren OE, Priefer R. Surface tension examination of various liquid oral, nasal, and ophthalmic dosage forms. Chemistry Central Journal. 2016;10(1):1-5. Available from: https://dx.doi.org/10.1186/s13065-016-0176-x. 